УДК 379.85

\title{
ВІРТУАЛЬНА ЕКСКУРСІЯ ЯК НАПРЯМОК РОЗВИТКУ СУЧАСНОГО ТУРИЗМУ
}

\section{VIRTUAL EXCURSION AS A DIRECTION OF THE DEVELOPMENT OF MODERN TOURISM}

\author{
Марусей Тетяна Володимирівна \\ кандидат економічних наук, доцент, \\ Кам'янець-Подільський національний університет імені Івана Огієнка \\ ORCID: https://orcid.org/0000-0002-1018-702X
}

\author{
Marusei Tetiana \\ Kamianets-Podilskyi Ivan Ohiienko National University
}

\begin{abstract}
У статті розглядаються віртуальні екскурсії як відносно нове явище в Україні. У статті обґрунтовано значення туризму, який відіграє велику роль в економіці будь-якої країни. І як всі успішні галузі він вимагає використання інновацій, в тому числі комп'ютеризованих. Автором визначено поняття, переваги та недоліки віртуальних екскурсій, їх фрункції. Наведено сучасні сервіси віртуальних турів. Аргументовано, що віртуальні музеї $є$ унікальною технологією, яка дозволяє розширити можливості e-Learning і освіти, зберегти культурну спадщину для нащадків і зробити відвідування будь-кого музею світу, природного дива або архітектурного шедевра доступним для всіх людей планети, що мають вихід в мережу Internet. Визначено, що існує велика кількість сайтів, що пропонують віртуальні екскурсії в різні місця по всьому світу та дозволяють досліджувати колекції творів мистецтва по всьому світу в найдрібніших деталях.
\end{abstract}

Ключові слова: екскурсія, віртуальна екскурсія, музей, віртуальний музей, подорож, туризм, віртуальний туризм.

В статье рассматриваются виртуальные экскурсии как относительно новое явление в Украине. В статье обосновано значение туризма, который играет большую роль в экономике любой страны. И как все успешные отрасли он требует использования инноваций, в том числе компьютеризированных. Автором определено понятие, преимущества и недостатки виртуальных экскурсий, их функции. Приведены современные сервисы виртуальных туров. Аргументировано, что виртуальные музеи являются уникальной технологией, которая позволяет расширить возможности e-Learning и образования, сохранить культурное наследие для потомков и сделать посещение любого музея мира, природного чуда или архитектурного шедевра доступным для всех людей планеты, имеющих выход в сеть Internet . Определено, что существует большое количество сайтов, предлагающих виртуальные экскурсии в разные места по всему миру и позволяют исследовать коллекции произведений искусства по всему миру в мельчайших деталях.

Ключевые слова: экскурсия, виртуальная экскурсия, музей, виртуальный музей, путешествие, туризм, виртуальный туризм.

The article considers virtual tours as a relatively new phenomenon in Ukraine. The article substantiates the importance of tourism, which plays an important role in the economy of any country. And like all successful industries, it requires the use of innovation, including computerized. The author defines the concepts, advantages and disadvantages of virtual tours, their functions. Modern services of virtual tours are given. It is argued that virtual museums are a unique technology that enhances e-learning and education, preserves cultural heritage for posterity and makes visiting any museum in the world, natural wonder or architectural masterpiece accessible to all people on the Internet. . It has been identified that there are a large number of sites that offer virtual tours of various places around the world and allow you to explore collections of works of art around the world in the smallest detail, as the site offers a selection of material in the following categories: artists, techniques, directions, historical events, historical figures, different places, and creating a virtual tour is a complex process that requires a lot of creative effort. But with the help of various web services and programs it is possible to turn a regular tour into a more convenient format for viewing anywhere and anytime. It is proved that it is in this context that virtual tours arose, due to: first, the need for a more interesting and emotionally rich, modern presentation of artistic information; secondly, the desire to get acquainted with the culture and art of different countries, to learn about the cultural monuments of different regions of the world; thirdly, by increasing the opportunities due to IT technologies to increase the information and cultural level of modern 
man. It has been studied that museums themselves, which are constantly developing a base of new methods for different audiences, direct their educational and educational activities to meet these needs. It is determined that many experts in the tourism industry believe that the development of virtual tourism will be one of the areas of the tourism industry, and virtual tours in the tourism industry are primarily a means of advertising and promotion.

Keywords: tour, virtual tour, museum, virtual museum, travel, tourism, virtual tourism.

Постановка проблеми. Туризм відіграє велику роль в економіці будь-якої країни. І як всі успішні галузі він вимагає використання інновацій, в тому числі комп'ютеризованих. Саме в цьому контексті виникли і віртуальні екскурсії, зумовлені: по-перше, потребами у більш цікавому й емоційно насиченому, сучасному поданні мистецької інорормації; по-друге, бажанням знайомитись із культурою та мистецтвом різних країн, пізнавати пам'ятки культури різних регіонів світу; по-третє, збільшенням можливостей завдяки IT-технологіям підвищити інформаційний та культурний рівень сучасної людини. На задоволення цих потреб спрямовують свою освітню і просвітницьку діяльність і самі музеї, які постійно напрацьовують базу нових методів для різних аудиторій. Багато фрахівців туристичної індустрії впевнені, що розвиток віртуального туризму стане одним з напрямів туристичної індустрії. Нині віртуальні екскурсії в туристичній галузі слугують, передусім, засобами реклами і просування.

Аналіз останніх досліджень і публікацій. Важливість дослідження впливу цифровізації на розвиток сучасної туристичної індустрії зумовила увагу до даної проблеми іноземних і вітчизняних вчених. Питаннями застосування цифрових технологій та мультимедіа для віртуалізації у сорері туризму й екскурсійної справи цікавилися такі вітчизняні науковці, як: К. Верес, О. Сущенко, О. Коваленко, О. Шликова, К. Вельтман, О. Лебедів, Я. Гаврилова, О. Ліпута та інші.

Виділення невирішених раніше частин загальної проблеми. Незважаючи на вагомий внесок учених та практичних працівників, застосування сучасних цисррових технологій у сорері туризму та екскурсійної справи досліджено недостатньо. Актуальним $є$ висвітлення як теоретичного, так і практичного аспектів щодо можливості впровадження віртуальних екскурсій у туристичну діяльність.

Формулювання цілей статті (постановка завдання). Розглянути теоретичні та практичні аспекти віртуальних екскурсій як напрямку розвитку сучасного туризму.

Виклад основного матеріалу дослідження. На сьогодні різні об'єкти культурної спадщини, такі як музеї, художні галереї, виставкові комплекси користуються віртуальною реальністю для створення віртуальних екскурсій. Саме віртуальні екскурсії імітують перебування людини на цих об'єктах, дають можливість перегляду всіх експозицій в будь-який зручний час і вирішують проблеми доступності, так як не кожен зможе відвідати особливо віддалені об'єкти в силу тих чи інших обставин. Віртуальні екскурсії фрормують музейну потребу - необхідність відвідувати музеї з метою самовдосконалення та (або) відпочинку та музейну культуру як сукупність знань, умінь та навичок поведінки в музеї, сприйняття інорормації, яку відображають музейні пам'ятки.

Спектр застосування віртуальних турів досить широкий. В першу чергу туризм, готельний і ресторанний бізнес. $\mathrm{Ha}$ webсторінках туристичних компаній все частіше можна зустріти віртуальні подорожі за світовими пам'ятками, що дозволяють здійснювати захоплюючі прогулянки 3 повним еоректом присутності, побувати в знаменитих місцях, побачити всю красу фрешенебельних готелів, а також попередньо оцінити інтер'єр, вид 3 вікна, місце розташування та атмоссреру номера. Забронювавши номер в готелі, мандрівники хочуть чітко розуміти, чого їм очікувати. Віртуальний тур дозволяє створити цілісне уявлення про готелі, наочно продемонструвавши всі їхні переваги та недоліки, не залишивши ніяких сумнівів у клієнта.

Саме поняття «віртуальний» трактується як «змодельований за допомогою комп'ютера» [2]. Термін «virtual» з англійської перекладається як «фрактичний» або «той, що відповідає дійсності». Отже, можна припустити, що віртуальний - це змодельоване явище за допомогою комп'ютерних технологій, але таке, що відповідає дійсному, існуючому в реальному житті. Перші віртуальні музеї стали з'являтися в Інтернеті в 1991 році. Вони представляли собою невеликі сайти 3 інфрормацією про самому музеї, про його геограсрічному положенні та режим роботи. Надалі на сторінках віртуальних музеїв стали з'являтися віртуальні експозиції. Багато музеїв створювали кілька віртуальних експозицій і об'єднували їх у віртуальні екскурсії. В даний час кількість і глибина викладеного 
матеріалу, доступного через мережу Інтернет, безперервно росте, і можливо, вже через кілька років свої власні віртуальні екскурсії матимуть всі музеї світу. Віртуальна екскурсія - це організаційна фрорма навчання, яка відрізняється від реальної екскурсії віртуальним відображенням реально існуючих об'єктів (музеї, парки, вулиці міст, тощо) 3 метою створення умов для самостійного спостереження, збору необхідних фрактів [2].

Віртуальна екскурсія - це комбінація панорамних фротограсрій (сореричних або циліндричних), коли перехід від однієї панорами до іншої здійснюється через активну зону (їх називають точками прив'язки або точками переходу), що розміщуються безпосередньо на зображеннях, а також з урахуванням плану туру. Все це може доповнюватися озвучуванням переднього плану і фронової музикою, а при необхідності і звичайними фротограсріями, відеороликами, flash-роликами, планами турів, поясненнями, контактною інформацією.

Так само великий потенціал віртуальні подорожі мають в освіті. Завдяки віртуальним подорожам можна відвідати будь-яку країну, будь-який куточок своєї країни, познайомитися з історичними пам'ятками, архітектурою, відвідати музей або виставку, що знаходиться в будь-якому місті світу. Подібні віртуальні уроки здатні не тільки зробити пізнавальний процес захоплюючим, але і більш ефективним, так як більшу частину інформації сприймається візуально. Таким чином, за допомогою віртуальних подорожей досягається принцип доступності освіти, розширюється кругозір, відбувається стимулювання пізнавальної активності і формується позитивна мотивація до навчання.

Сорера застосування віртуальних турів досить широка і інтерес до неї росте, тому технології створення віртуальних подорожей, активно розвиваються та вдосконалюються. У багатьох країнах вже існують різні віртуальні тури і екскурсії по популярних у туристів дестинаціях. Серед культурно-освітніх установ світу, що використовують подібну технологію і надають такі можливості, можна виділити Лувр (Франція), Ермітаж (Росія), музей Метрополітен у Нью-Йорку (США) та інші галереї й музеї Європи. У кожного музею $є$ web-сайт, на якому пропонуються розроблені працівниками музею віртуальні екскурсії для певного кола глядачів (переважно для підліткового віку та дорослих). Ці екскурсії не обмежені в часі, оскільки кожен може будь-коли зайти на сайт і перебувати в залах музею, скільки заманеться. Глядачам пропонується перегляд картин, кераміки, скульптури, які зберігаються у залах музеїв. Такі екскурсії мають оглядовий характер, а це є певним вразливим місцем такого типу екскурсій, оскільки глядач не матиме повної інформації про той чи інший твір. Велика кількість музейних експонатів знаходиться в фрондосховищах, а власні сайти мають не всі музеї. Тому, розробивши і просунувши свій сайт, музей може не тільки заявити про себе, а й приймати інтернет-екскурсантів, а також відкрити всі свої фронди.

Серед музеїв України, за якими розроблені віртуальні тури та екскурсії, можна виділити: художні музеї, музеї-заповідники, етнографрічні музеї, палеонтологічні музеї, військові музеї та історико-меморіальні комплекси, музеї техніки. Окрім світових музеїв, віртуальні екскурсії пропонують також вітчизняні, але переважно це історичні (музей М. Грушевського: http://incognita.day.kiev.ua/museums/ hetmanstva/museum.swf) або етнографрічні (Музей писанкового розпису в Коломиї: http://hutsul.museum/pysanka/) [3; 4; 5; 7; 9].

Обов'язковими умовами підготовки та розміщення віртуальної екскурсії $€$ наявність не менше двох приміщень / залів для надання послуг; не менше двох видів послуг, що надаються; вміння виділити та продемонструвати свої переваги.

У віртуальних екскурсій $є$ свої переваги та недоліки. Основними перевагами є: доступність - можливість огляду визначних пам'яток всього світу без великих матеріальних і тимчасових витрат; можливість багаторазового перегляду екскурсій і опису об'єктів в будьякий час; отримання вражень - за допомогою екскурсії створюється ефект присутності, у користувача $€$ можливість оглядати приміщення на всі 360 градусів; можливість бути всередині картинки - важливо подивитися на екрані, а потім поїхати і побачити наживо; практичність для сайту і туристичного підприємства - витрати на виготовлення та розміщення віртуальної екскурсії не вимагають великих вкладень, але дають великий ефект при успішній рекламі; отримання широкого спектру інсрормації - статті з детальним описом послуг, що надаються, безумовно, гарні, однак, не дають можливості подивитися, як все виглядає в реальності; можливість взаємодії з відвідувачами без посередників яскравою технологією візуалізації, яка дозволить дуже швидко, без участі людського ресурсу познайомити всіх відвідувачів сайту з наочно представленою інфрормацією [6]. 
Розглянемо основні недоліки віртуальних екскурсій. Насамперед, це неможливість поставити запитання в режимі реального часу; залежність від творців - неможливо побачити те, що не включено в екскурсію; обмеженість вражень як один з основних недоліків.

Якщо говорити стосовно сервісів, які можуть допомогти кожному із користувачів, здійснити невелику подорож по місту.

Сучасним інформаційним продуктом $є$ віртуальні виставки, для створення яких широко використовують різноманітні онлайн сервіси, наприклад, Calameo, YouTube, ISpring тощо. До речі, онлайн сервісів в інтернеті безліч, майже всі можна пристосувати для розміщення будь-якої інфрормації, і на виході отримати привабливий та якісний інформаційний продукт. Зважаючи на те, що інтернет наразі $\epsilon$ високошвидкісним, коректне відображення цього продукту цілком залежить від техніки і програмного забезпечення.

Особливої уваги заслуговують онлайн сервіси компанії Google. Досить багато українців, що мають доступ до інтернету зі своїх персональних комп'ютерів, користуються браузеpoм Google Chrome, який є найпопулярнішим серед українців мобільним браузером і браузером для смарторонів. Медійний продукт, створений у Google сервісі, доступний у будьякий час не тільки з будь-якого комп'ютера, але і з мобільного пристрою, тому цілком вірогідно, що саме цей продукт побачить якнайбільше користувачів. Для роботи у цих сервісах потрібно мати встановлений браузер Chrome, а також Google аккаунт.

Наразі великою популярністю користуються віртуальні екскурсії та інтерактивні подорожі. Завдяки сервісам Google кожен, хто має доступ до системи Інтернет, може не тільки здійснювати віртуальну подорож, але й створювати ї̈. Це можуть бути книжкові виставки-подорожі: подорож населеними пунктами; екскурсії по визначних пам'ятках і пам'ятними місцями; маршрути, пов'язані 3 іменами відомих людей, земляків; подорожі разом 3 літературними героями; подорожірозповіді про історичні події.

Google пропонує безкоштовні онлайн сервіси для самостійного створення віртуальних екскурсій і цифрових подорожей.

Онлайн сервіс Tour Builder створений на основі Google мапи та інструменту Google Earth (Google Планета Земля). За допомогою цього сервісу можна швидко і просто створити унікальний 2D або 3D-тур: потрібно лише вибрати маршрут, додати опис, фоотограсрії, відео [8]. ще один цікавий сервіс StoryMapJS дозволяє створити необмежену кількість віртуальних подорожей у вигляді інтерактивних мап. У результаті виходить оригінальна презентація: мапа, на якій показано місце події, і слайди з розповіддю, на які можна додати фотограсрії, відео або аудіо. На мапі можна дізнатись точну адресу музею, а на слайдах представлені фото, відео, текстова інорормація про заклад, а також корисні посилання.

У 2018 році компанія Google випустилаінструмент для викладачів і учнів Tour Creator, який дозволяє створювати віртуальні тури, використовуючи зображення з Google Street View або власні 360-градусні фротографpiï. Google Street View - фрункція панорамного перегляду вулиць по всьому світу, що надається через розширення Мапи Google та Google Земля.

Дуже популярний сервіс 360Cities - це галерея 3D-панорам 3 усього світу. Ha 360Cities можна знайти панорами-чемпіони гігантських розмірів - зараз рекордсменом $€$ вид Лондона на 320 гігапікселів. Збільшення зображення можливо навіть до окремих пішоходів, які йдуть по вулиці або стоять на зупинці в очікуванні автобуса. Ha 360Cities представлені різноманітні повітряні, наземні та підводні пейзажі, будинки і будівлі, вулиці та парки, внутрішній інтер'єр популярних публічних місць і закладів [2].

360Cities має корисний режим сполучення 3 картою Google Maps і розвинену навігацію. Досить зручні, виявилися розділи «Популярні місця» і «Популярні панорами». Кожна панорама має можливість додавання на будь-який сайт. Українськими аналогами даного сервісу $\epsilon$ «PanoVision» і «City360», але їх географрія орієнтується виключно на туристичні об'єкти України [2]. Портал «PanoVision» являє собою структурований інтернет-каталог віртуальних турів по різних об'єктах, виконаних 3 використанням технології панорамної фротозйомки та спрямованих на продаж панорам. На сьогоднішній день портал налічує понад 15000 панорам і по праву вважається одним із найбільших в Україні. Всі панорами розподілені за основними напрямками: Харків, Київ, Карпати, Одеса, Дніпропетровськ, Запоріжжя. Відвідувачі порталу отримують можливість в будь-який час випробувати ефект присутності на реальному об'єкті, будь-то об'єкт житлової або комерційної нерухомості, готель, ресторан, заочно відвідати будь-який масовий захід або пам'ятку архітектури.

Існує велика кількість сайтів, що пропонують віртуальні екскурсії в різні місця по всьому світу. Варто приділити увагу проекту 
Google Arts \& Culture, який дозволяє досліджувати колекції творів мистецтва по всьому світу в найдрібніших деталях. Сайт пропонує підбір матеріалу за наступними категоріями: художники, техніки, напрямки, історичні події, історичні особистості, різні місця. Тут можна знайти віртуальні екскурсії по Британському музею, Національної галереї, музею Вікторії та Альберта, собору Святого Павла, галереї Тейт і багатьом іншим [8].

Висновки. Таким чином, з огляду на все вищесказане, можна зробити висновок про те, що віртуальні екскурсії мають великий потенціал, ще не до кінця оцінений в Україні. Вони мають свої переваги, можуть бути особливо затребуваними у певних категорій населення, $\epsilon$ хорошим засобом реклами для музею та сприяють розвитку туристичного попиту, а віртуальний туризм став інноваційним засобом реклами національного туристичного продукту та презентації туристичного потенціалу. В таких умовах використання віртуальних технологій, як порівняно простих у виготовленні віртуальних екскурсій, так і віртуальних турів, що дають людині ефеект занурення, присутності в музеї - $\epsilon$ дуже ефективним способом залучення уваги користувачів Інтернету до реально існуючого музею. Безсумнівно, що лише музей, який має хороший сайт, з представленою на ньому віртуальною екскурсією або віртуальним туром по музею може зацікавити сучасного мандрівника.

\section{СПИСОК ВИКОРИСТАНИХ ДЖЕРЕЛ:}

1. Верес К.О. Інноваційні технології в екскурсійному супроводі. URL: http://dspace.nuft.edu.ua/jspui/ bitstream/123456789/17392/3/Innovative\%20technology\%20of\%20excurtion\%20accompanied.pdf

2. Коваленко О.В. Використання віртуальних екскурсій як сучасних форм організації навчального процесу. URL: http://www.innovpedagogy.od.ua/archives/2019/9/part_1/22.pdf

3. Музеї онлайн. URL: http://incognita.day.kyiv.ua/infohraphics

4. Музеї України просто неба. URL: https://museums.authenticukraine.com.ua/ua/

5. Національний художній музей України. Просвітницькі програми музею. URL: http://namu.kiev.ua/ua/ educational-programs/namu.html

6. Сущенко О.А., Кравченко В.В. Становлення віртуального туризму як напряму розвитку інфрорматизації діяльності туристичного підприємства. URL: http://nbuv.gov.ua/UJRN/kgm_tech_2018_140_6

7. Кращі музеї, куди можна потрапити онлайн. URL: https://34travel.me/post/online-museums

8. Сервіс Google Arts and Culture. URL: https://artsandculture.google.com/

9. 41 найкращий віртуальний музей світу, який необхідно відвідати. URL: https://www.canva.com/ru_ru/ obuchenie/virtualnye-ekskursii/

\section{REFERENCES:}

1. Veres K.O. Innovatsiini tekhnolohii v ekskursiinomu suprovodi [Innovative technologies in excursion accompaniment]. Retrieved from: http://dspace.nuft.edu.ua/jspui/bitstream/123456789/17392/3/Innovative\%20technology\%20of\%20excurtion\%20accompanied.pdf

2. Kovalenko O.V. Vykorystannia virtualnykh ekskursii yak suchasnykh form orhanizatsii navchalnoho protsesu [Using of virtual tours as modern forms of organization of the educational process]. Retrieved from: http://www.innovpedagogy.od.ua/archives/2019/9/part_1/22.pdf

3. Muzei onlain [Museums online]. Retrieved from: http://incognita.day.kyiv.ua/infohraphics

4. Muzei Ukrainy prosto neba [Open-air museums of Ukraine]. Retrieved from: https://museums.authenticukraine.com.ua/ual

5. Natsionalnyi khudozhnii muzei Ukrainy. Prosvitnytski prohramy muzeiu [National Art Museum of Ukraine. Educational programs of the museum]. Retrieved from: http://namu.kiev.ua/ua/educational-programs/namu.html

6. Sushchenko O.A., Kravchenko V.V. Stanovlennia virtualnoho turyzmu yak napriamu rozvytku informatyzatsii diialnosti turystychnoho pidpryiemstva [Formation of virtual tourism as a direction of development of informatization of activity of the tourist enterprise]. Retrieved from: http://nbuv.gov.ua/UJRN/kgm_tech_2018_140_6

7. Krashchi muzei, kudy mozhna potrapyty onlain [The best museums where you can get online]. Retrieved from: https://34travel.me/post/online-museums

8. Servis Google Arts and Culture [Google Arts and Culture service]. Retrieved from: https://artsandculture. google.com/

9. 41 naikrashchyi virtualnyi muzei svitu, yakyi neobkhidno vidvidaty [41 best virtual museums in the world to visit]. Retrieved from: https://www.canva.com/ru_ru/obuchenie/virtualnye-ekskursii/ 